\title{
High-heat-producing granites of East Dharwar Craton around Gugi, Karnataka, and their possible influence on the evolution of Rajapur thermal springs, Deccan Volcanic Province, India
}

\author{
Hemant K Singh ${ }^{1 *}$, Yadvendra Kumar ${ }^{1}$, Dornadula Chandrasekharam ${ }^{1}$, Trupti Gurav ${ }^{1}$ and Banambar Singh ${ }^{1,2,3}$
}

* Correspondence:

hemantkrsingh25@gmail.com

'Department of Earth Sciences, Indian Institute of Technology Bombay, Mumbai, Maharashtra 400076, India

Full list of author information is available at the end of the article

\begin{abstract}
Background: The thermal springs of Rajapur situated along the west coast of Maharashtra and parts of high-heat-generating granites of Gugi in Karnataka (India) seem to be genetically related. The present investigation involves quantification of the heat generated by the Gugi Granites using the the $U$, Th and $K$ contents in the rock samples and probing their possible influence on the evolution of the Rajapur springs, based on the geochemistry of the thermal waters, published Bouguer gravity anomaly data, and the overall geological setup.
\end{abstract}

Methods: Fourteen water samples from Rajapur including thermal and groundwater samples were analysed for major ions and five rock samples from the gugi area were analysed for U, Th and $\mathrm{K}$.

Results: Rajapur thermal spring is of $\mathrm{Na}-\mathrm{HCO}_{3}$ type, while other thermal springs along the west coast are either $\mathrm{Na}-\mathrm{Cl}$ type or $\mathrm{Na}-\mathrm{Cl}-\mathrm{CO}_{3}$ type. The stable isotope data of the thermal waters signifies mixing with the ground water. The gravity anomaly data supports the extension of the Gugi Granites below the Deccan Volcanics of the study area.

Conclusions: The present investigation suggests that the Gugi Granites could be the main source of heat for these thermal springs, even though the springs issue through the Deccan volcanic flows.

Keywords: Heat source; Rajapur thermal springs; Gugi Granite; Heat generation

\section{Background}

The Rajapur thermal springs belong to a group of thermal springs located along the west coast of India, which emerge through the 65 Ma Deccan Flood Basalt (DFB). The western margin of the Deccan Trap is characterized by these thermal springs, extending for a distance of about $300 \mathrm{~km}$ along the Konkan coast in the Thane, Raigad, and Ratnagiri districts of Maharashtra (Chandrasekharam 2005; Kumar et al. 2011). Although these springs discharge through the Deccan Volcanics, some of them show a close relationship to the Precambrian gneissic and granitic basement (Ramanathan and Chandrasekharam 1997). Along the western margin of the Deccan Volcanic Province (DVP), an approximately 1,000-m-thick sequence of near horizontal lava flows is 
exposed, overlying Precambrian sedimentary and meta-sedimentary (Kaladgi and Dharwar) rocks and Archaean crystallized complex (Kumar et al. 2011). Basaltic lava flows that overlie the older rocks of Dharwar and Kaladgi are both of 'a'a and Pahoehoe types (Sahasrabudhe et al.: A geological report on the Koyna earthquake of 11.12.67, unpublished work; Ghodke et al.: West coast geothermal investigation, District Ratnagiri, unpublished work). In the southern portion of DVP, flows are characterized by the 'a'a type, e.g., in the Ratnagiri district, Maharashtra (Kumar et al. 2011). Large outcrops of these granites can be found towards the south and southeast of the DVP. The nearest location (350 km from Rajapur) of such an outcrop is encountered at Gugi in Karnataka (Figure 1), where granites with high $U$ and Th content have been reported (Senthil Kumar and Srinivasan 2002). Further, these granites also host uranium veins (Senthil Kumar and Srinivasan 2002). Such granites also occur as inliers, as encountered south of Rajapur (Ramanathan and Chandrasekharam 1997).

The present investigation deals with the possible influence of high-heat-producing granites of Gugi on the propagation of the Rajapur thermal springs. With the help of gravity anomaly data (GSI in 2006), an attempt has been made to find the extent of these granites below the volcanic flows at the thermal springs site.

\section{Geology of Rajapur thermal spring site}

DVP is one of the world's largest continental flood basalts, which are spread out over the north-western, central, and southern Indian Peninsula, with a total exposed area of about $5.0 \times 10^{5} \mathrm{~km}^{2}$. The total thickness of the basalt lava flows varies from 2,500 to $3,000 \mathrm{~m}$ along the west coast, decreasing gradually towards the east. The Deccan Trap flows are traversed by a large number of N-S trending faults and dyke swarms (Hooper 1990). The thermal springs on the west coast are aligned along this major tectonic feature, i.e., the West Coast Fault (Chandrasekharam 1985; Minissale et al. 2000). The geothermal gradient, deciphered from the study of boreholes, is about $57^{\circ} \mathrm{C} / \mathrm{km}$ (Chandrasekharam 2000). In the Rajapur area, the thickness of the basalt flows is approximately $600 \mathrm{~m}$ (Figure 2) (Subbarao et al. 1994). The study area is dominated by the highly fractured Deccan Basalt. In some places, scoria and layering in basalt are also present. This is where both cold springs $\left(<27^{\circ} \mathrm{C}\right)$ and thermal springs $\left(41^{\circ} \mathrm{C}\right.$ to $\left.72^{\circ} \mathrm{C}\right)$ are present.

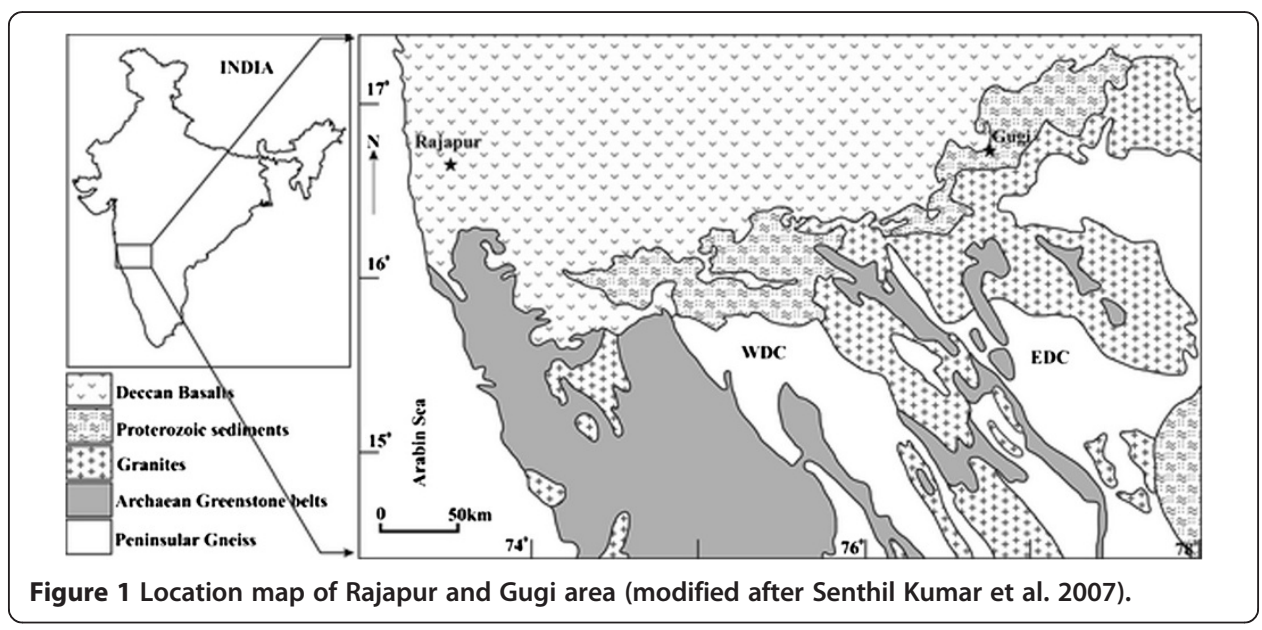




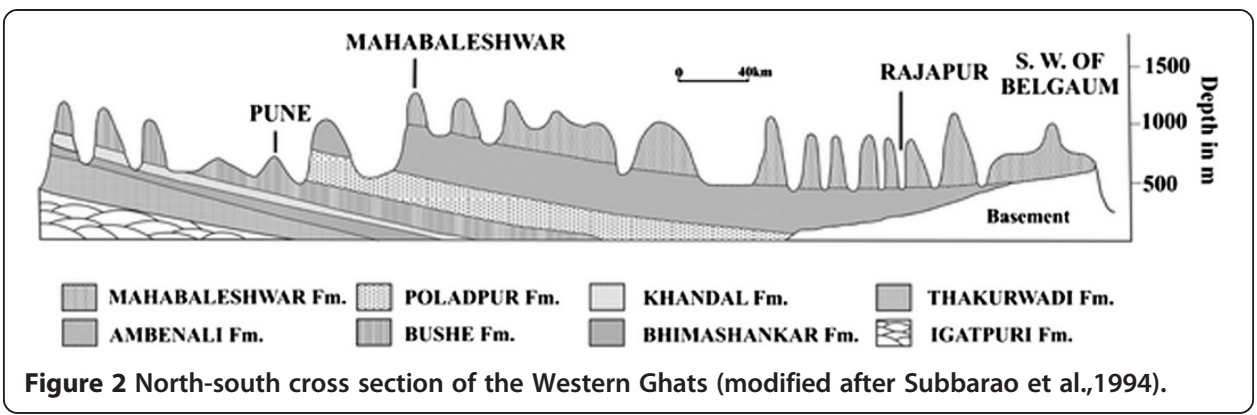

\section{Geology of the Gugi Area}

The major exposed rock type is Closepet Granite at the western margin of the Eastern Dharwar Craton (Swaminath and Ramakrishnan 1981), where it meets with the Bhima Basin. The basement of Neoproterozoic Bhima Group consists of the Late Archean granitoid, which can be seen exposed along the southern margin of the Bhima Basin (Figure 3). These granitoid rocks are rich in $\mathrm{U}$ - and Th-containing minerals such as sphene, apatite, and zircon (Senthil Kumar and Srinivasan 2002; Senthil Kumar and Reddy 2004). Closepet Granite Suite also contains K-rich granitoids in which uranium mineralization is reported (Senthil Kumar and Srinivasan 2002). Most of the uranium mineralization is within the Archean granitoids of Dharwar Craton and Neoproterozoic fault of Bhima Group of rocks (Pandit et al. 1999; Dhana Raju et al. 1999). The available heat flow data in the Dharwar Craton ranges between 25 and $51 \mathrm{~mW} / \mathrm{m}^{2}$ (Senthil Kumar and Reddy 2004).

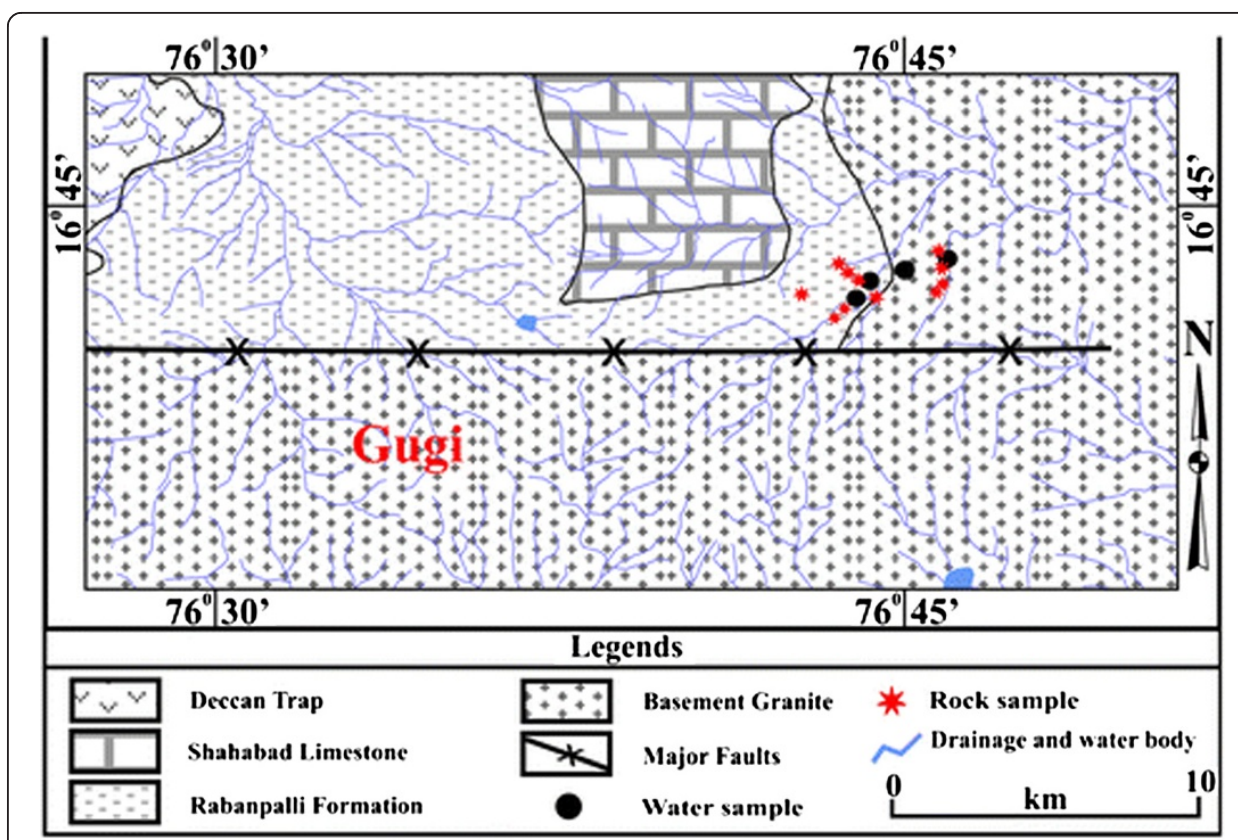

Figure 3 Bhima Basin in East Dharwar craton and location of water and rock samples. Bhima Basin in East Dharwar craton and location of water and rock samples collected in parts of the Gugi area (modified after Kale and Peshwa 1995; Vaidyanadhan and Ramakrishnan 2010). 
A detailed geological map was prepared based on the field observations around Gugi. The Archaean Granite is exposed with Proterozoic sediments, which are mostly carbonates of the Bhima Group. Both are in contact with an E-W trending reverse fault, steeply dipping towards the north, known as 'Gugi-Karalagere fault', extending up to Karalagere in the west with a maximum width of $500 \mathrm{~m}$. This fault, cutting across the carbonate and granitoid rocks and horizontal beds of sedimentary formation of the Neoproterozoic Bhima group, forms steep dips in the fault zone. Lamination, brecciation, and asymmetric folds are clearly observed in the carbonate rocks.

Occasionally, small blocks of granite are exposed around Gugi. Grey and purple shale, limestone, and basement conglomerate of the Bhima Basin are exposed along the fault zone. Dark-colored, coarse-grained blocks of peninsular gneiss are also observed in several places. Grey soil is observed because of the presence of phosphate in the Bhima Basin sediments.

\section{Methods}

\section{Sample collection and water analysis}

Representative rock and water samples were collected from Gugi area (Figure 3), while only the water samples were collected from the Rajapur area (Figure 4). All the water samples were collected in two sets. One set of water samples was acidified with $\mathrm{HNO}_{3}$ (with $5 \mathrm{~mL} 14 \mathrm{M}$ ultrapure $\mathrm{HNO}_{3} / \mathrm{L}$ ) on site, and the other set was stored at a lower temperature for future analysis (Arnorsson 2000; Marini 2010). The water samples from Rajapur include samples from thermal springs, rivers, bore wells, and ponds. Temperature and $\mathrm{pH}$ were measured in the field using an ORION pH meter (Thermo Fisher Scientific, Hudson, NH, USA).

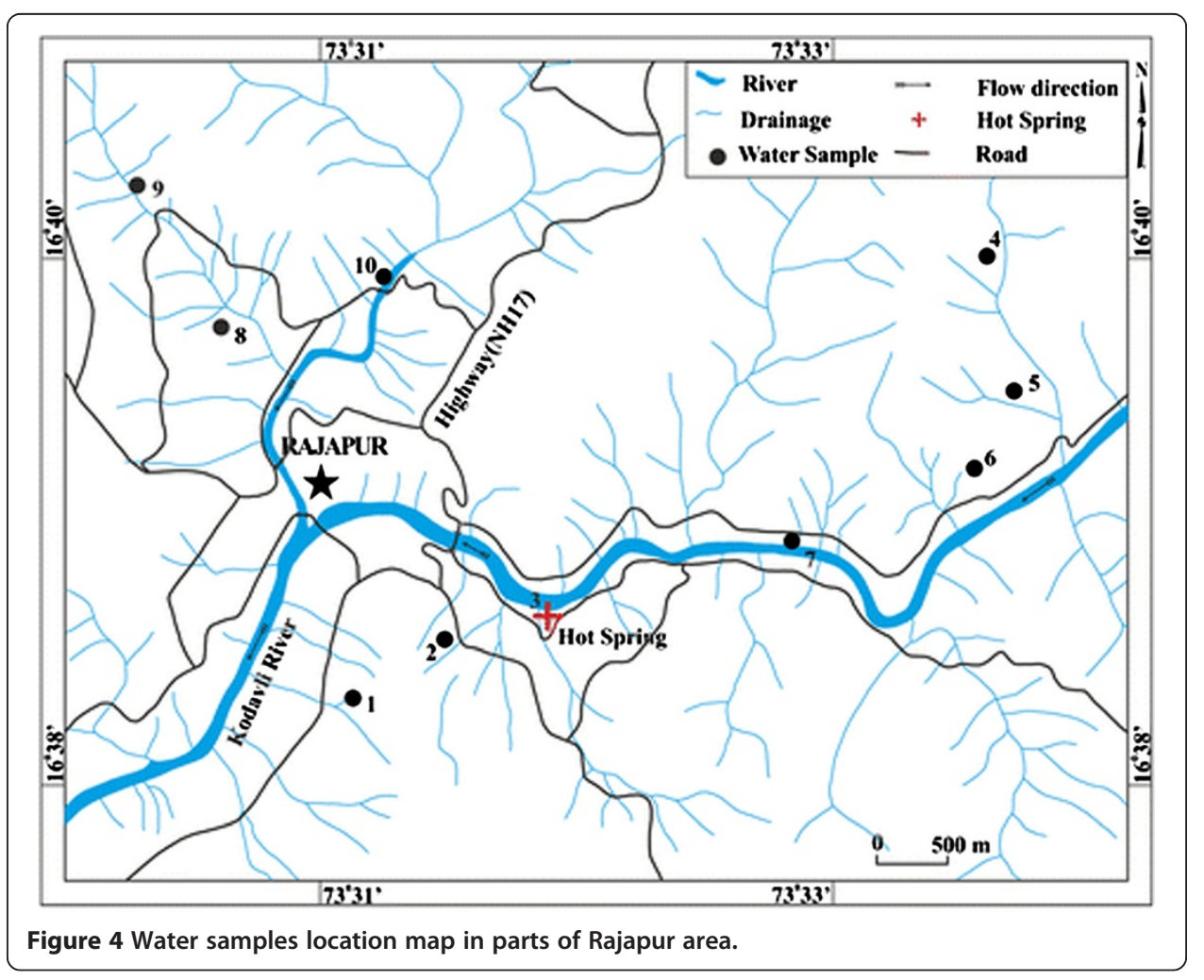


Table 1 Physical and chemical parameters of water samples from the study area

\begin{tabular}{|c|c|c|c|c|c|c|c|c|c|c|c|c|}
\hline Serial no. & Sample name & Temp $\left({ }^{\circ} \mathrm{C}\right)$ & $\mathrm{pH}$ & TDS & $\mathrm{Na}^{+}$ & $\mathrm{K}^{+}$ & $\mathrm{Ca}^{++}$ & $\mathrm{Mg}^{++}$ & $\mathrm{Cl}^{-}$ & $\mathrm{SO}_{4}{ }^{2-}$ & $\mathrm{HCO}_{3}{ }^{-}$ & $\mathrm{SiO}_{2}$ \\
\hline 1 & RGW & 26.5 & 6.5 & 54 & 3.7 & 0.01 & 4 & 2.4 & 6.5 & 4.3 & 16 & 8.3 \\
\hline 2 & RGW & 24 & 7 & 87 & 3.9 & 0.1 & 7 & 8.7 & 8.5 & 5.3 & 50 & 8.3 \\
\hline 3 & RTw & 41 & 8.3 & 557 & 74.6 & 11.8 & 43.1 & 11.6 & 17.6 & 11.9 & 340 & 52.5 \\
\hline 4 & RGW & 26 & 7 & 96 & 3.5 & 0.1 & 14 & 3.9 & 9.7 & 8.7 & 40 & 13.1 \\
\hline 5 & RGW & 27 & 6 & 138 & 6.9 & 1.6 & 12.6 & 2.4 & 10.4 & 4.6 & 50 & 24 \\
\hline 6 & RGW & 26 & 6.7 & 277 & 4.2 & 0.01 & 31.1 & 10.6 & 10.2 & 9.9 & 120 & 56.6 \\
\hline 7 & RSW & 26.4 & 7.6 & 156 & 3.1 & 0.4 & 18 & 7.7 & 8.4 & 7.3 & 75 & 27.5 \\
\hline 8 & RGW & 26 & 7 & 621 & 13.1 & 0.45 & 50.1 & 6.2 & 12.9 & 8.1 & 180 & 86.1 \\
\hline 9 & RSW & 27 & 6.5 & 104 & 3.8 & 0.3 & 12 & 7.3 & 9 & 8.7 & 60 & 8.9 \\
\hline 10 & RSW & 26 & 7 & 91 & 4.2 & 0.4 & 12 & 2.4 & 7.3 & 8.9 & 40 & 11.8 \\
\hline 11 & GWs & 26.7 & 7.6 & 219 & 65.5 & 2.7 & 38.1 & 22.7 & 77.5 & 55.1 & 185 & 19.6 \\
\hline 12 & GWs & 27 & 7.9 & 358 & 101.8 & 3.7 & 32.1 & 29.6 & 99.3 & 44.1 & 275 & 13 \\
\hline 13 & GWs & 26 & 7.5 & 497 & 130.2 & 3 & 102.3 & 11.5 & 202 & 47.6 & 275 & 1.7 \\
\hline 14 & GWs & 26 & 7 & 412 & 101.1 & 14.6 & 111.3 & 15.5 & 137 & 50.3 & 370 & 29.4 \\
\hline
\end{tabular}

The water samples were analyzed for major cation and anion concentrations. Cations and silica were analyzed using inductively coupled plasma atomic emission spectroscopy (ICP-AES). The sulphate concentration was measured with the aid of a UV spectrophotometer and alkalinity by a $\mathrm{H}_{2} \mathrm{SO}_{4}$ titration and chloride using the ion selective electrode method (Table 1). These analyses were conducted as per the standard procedures (APHA 1977).

\section{Estimation of radioactive heat}

The radioactive heat production (RHP in $\mu \mathrm{W} / \mathrm{m}^{3}$ ) of granite was calculated by taking into account the heat generation constant (amount of heat released per gram $\mathrm{U}, \mathrm{Th}$, and $\mathrm{K}$ per unit time) and the uranium, thorium, and potassium concentration $C_{\mathrm{U}}, C_{\mathrm{Th}}$, $C_{\mathrm{K}}$ present in rock (Rybach 1976; Cermak et al. 1982):

$$
\mathrm{RHP}=\rho\left(9.52 C_{\mathrm{U}}+2.56 C_{\mathrm{Th}}+3.48 C_{\mathrm{K}}\right) \times 10^{-5}
$$

where $\rho$ is the bulk density of rock in kilogram per cubic meter, $C_{\mathrm{U}}$ and $C_{\mathrm{Th}}$ are in weight parts per million, and $C_{\mathrm{K}}$ is in weight percent.

To determine the $U$ and Th concentrations in rock samples, powdered samples of less than 200 mesh were mixed with cellulose in a 4:1 ratio (Bertin 1978) to form pellets, which were analyzed by XRF. For potassium, powdered rock samples were diffused with lithium meta-borate and tetra-borate to make a rock solution then analyzed by

Table $2 \mathrm{U}$, Th (in ppm), and $\mathrm{K}(\%)$ values in selected rock samples

\begin{tabular}{llllll}
\hline Sample no. & $\mathbf{U}(\mathbf{p p m})$ & Th $(\mathbf{p p m})$ & $\mathbf{K}(\mathbf{w t} . \%)$ & RHP $\left(\boldsymbol{\mu W} / \mathbf{m}^{3}\right)$ & Heat flow $\left(\mathbf{m W} / \mathbf{m}^{2}\right)$ \\
\hline L2 & 1.1 & 66.8 & 0.2 & 4.92 & 44.9 \\
L3 & 6.1 & 4.7 & 5.8 & 2.43 & 42.4 \\
L4 & 3.2 & 1.0 & 1.6 & 1.04 & 41.0 \\
L5 & 4.8 & 5.7 & 5.3 & 2.13 & 42.1 \\
L16 & 6.4 & 1.0 & 5.9 & 2.28 & 42.3 \\
\hline
\end{tabular}


ICP-AES. The RHP from the granites of Gugi is shown in Table 2. In the present investigation, the heat flow value of the area was measured by the relationship between the radioactive decay to the surface heat flow described by the following equation (Birch et al. 1968; Lachenbruch 1968):

$$
Q=Q_{0}+D \times A
$$

where $Q$ is the heat flow at the surface, $Q_{0}$ is an initial value for heat flow unrelated to the specific decay of radioactive element at the current time, $D$ is the thickness of crust over which the distribution of radioactive elements is more or less homogeneous, and $A$ is the heat production rate per volume of rock (Glassley 2010). Assuming that the background heat flow is approximately $40 \mathrm{~mW} / \mathrm{m}^{2}$ (Glassley 2010), then heat flows of the location are given in Table 2.

Gugi is located in the Eastern Dharwar Craton (EDC) where the heat flow values range between 25 and $51 \mathrm{~mW} / \mathrm{m}^{2}$ (Senthil Kumar and Reddy 2004), common to the all Archean provinces (Jaupart and Mareschal 1999). In the Gugi granites, the observed concentration of $\mathrm{U}$ is at 1.1 to $6.4 \mathrm{ppm}$, Th at 1.0 to $66.8 \mathrm{ppm}$, and $\mathrm{K}$ at 0.2 to $5.9 \mathrm{ppm}$, and the average heat flow value is $42.5 \mathrm{~mW} / \mathrm{m}^{2} / \mathrm{m}$ (Table 2). However, in the Deccan basalt province, the average concentration of $\mathrm{U}$ is at 0.64 to $1.79 \mathrm{ppm}$, Th at 0.54 to $1.32 \mathrm{ppm}$, and $\mathrm{K}$ at 0.17 to $0.34 \%$ (Paul et al. 1984). These values indicate the RHP value to be in the range of 0.27 to $0.59 \mu \mathrm{W} / \mathrm{m}^{3}$ which is much less than that of Gugi granites, signifying the role of Gugi granites in the propagation of the Rajapur thermal springs.

\section{Results and discussion}

\section{Hydrogeochemistry}

Earlier studies carried out on the West Coast thermal springs have shown a high Na content (Ramanathan and Chandrasekharam 1997; Minissale et al. 2000), and most of the thermal springs are of the $\mathrm{Na}-\mathrm{Ca}-\mathrm{Cl}$ and $\mathrm{Ca}-\mathrm{Na}-\mathrm{Cl}$ types, mainly due to the interaction with seawater (Muthuraman 1986). However, the Rajapur thermal spring which is also along the west coast is of $\mathrm{Na}-\mathrm{HCO}_{3}$ type. The thermal spring is slightly alkaline in nature $\left(\mathrm{pH}=8.3\right.$ at $\left.25^{\circ} \mathrm{C}\right)$ with $557 \mathrm{mg} / \mathrm{L}$ total dissolved solids. The $\mathrm{SiO}_{2}$ concentration in the thermal water is slightly lower than some of the groundwater which can be attributed to the precipitation of $\mathrm{SiO}_{2}$ during its ascent. The ionic concentrations measured during the present investigation are shown in Table 1 and were plotted with water-rock interaction data from Singh et al. (2012) in Piper trilinear diagram (Piper; Figure 5). The plots clearly indicate that the thermal spring water is $\mathrm{Na}-\mathrm{HCO}_{3}$ type. The data fall in the secondary alkalinity field (Figure 5) dominated by the alkaline earths $\left(\mathrm{Ca}^{2+}, \mathrm{Mg}^{2+}\right)$ and weak acids $\left(\mathrm{HCO}_{3}^{-}\right)$. Well, river, and pond water samples are also $\mathrm{Ca}-\mathrm{HCO}_{3}$ type, and their chemistry is compatible with the chemistry of the rocks through which they flow. In the Piper diagram (Figure 5), surface and cold spring waters plot in almost the same field, indicating that they are recharged through meteoric water. The amount of total dissolved solids in the thermal water is found to be about $550 \mathrm{ppm}$ in Rajapur, while in Gugi area it varies from 220 to $500 \mathrm{ppm}$ in the water samples.

To understand the circulation of the water through the Gugi granite, we conducted water-rock interaction experiment for selected granite samples. The granite 


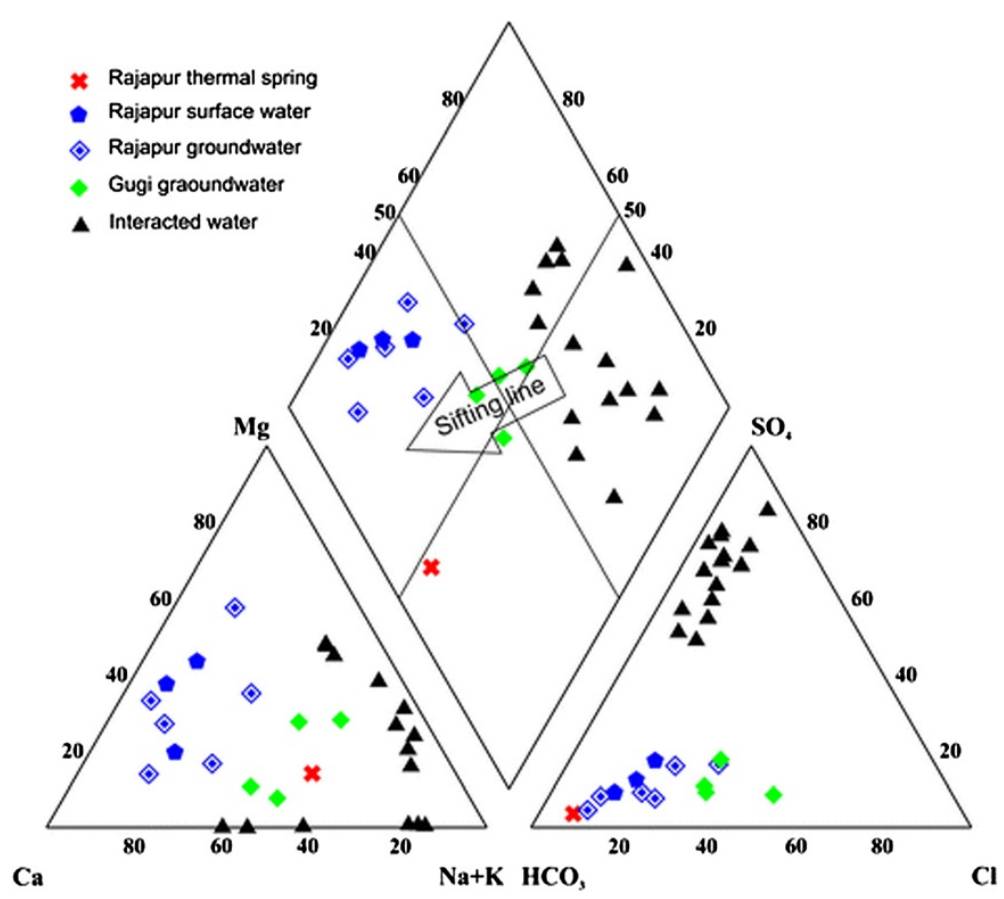

Figure 5 Piper (1944) trilinear diagram, showing the geochemical variation of different water types from study area.

samples were crushed to $<1 \mathrm{~mm}$. The water-rock interaction experiment was carried out in a glass chamber with fluid/solid ratio of $10: 1$ at $100^{\circ} \mathrm{C}$. Rainwater was utilized in the experiment as the interacting fluid. Water-rock interaction experiment with samples derived from the granites shows wide range of geochemical variation. Most of them fall in the $\mathrm{Na}_{-} \mathrm{SO}_{4}$ field (Singh et al. 2012), while the thermal springs and the surface waters fall in the $\mathrm{Ca}-\mathrm{HCO}_{3}$ field (Figure 5). It indicates circulation of meteoric water within the granites (host of the thermal reservoir) and emerging through the Deccan Basalt flows, after mixing with the near-surface groundwater and thus becoming rich in $\mathrm{Ca}-\mathrm{HCO}_{3}$ component. It further

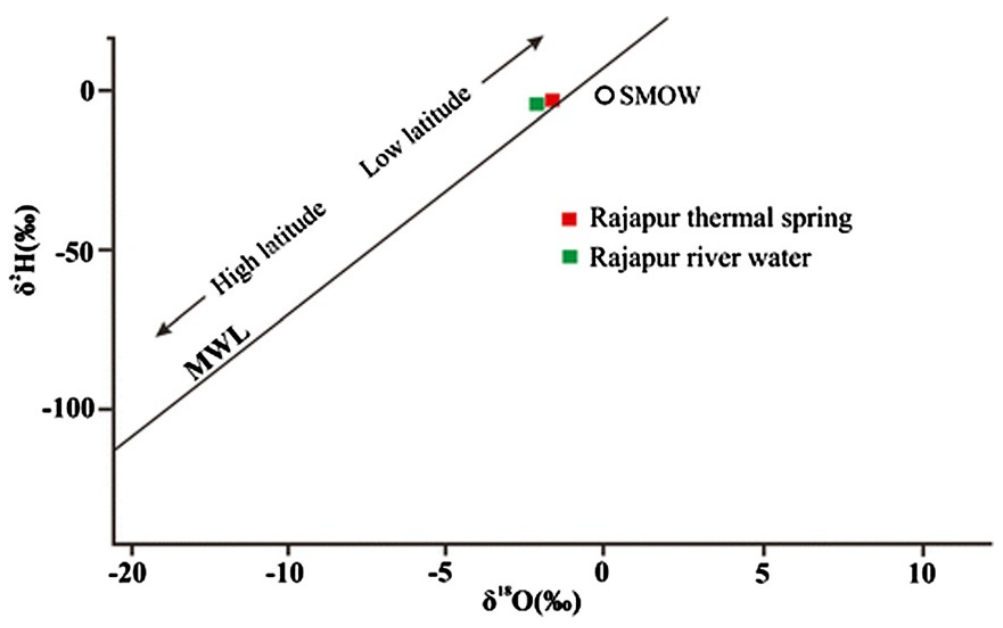

Figure 6 Oxygen and hydrogen isotope variation in the Rajapur thermal spring. 
strengthens our earlier view (Chandrasekharam and Chandrasekhar 2010) that the granites are the main source of heat for the thermal springs in several geothermal provinces of India.

\section{Isotope data}

The stable $\left(\delta^{18} \mathrm{O}\right.$ and $\left.\delta^{2} \mathrm{H}\right)$ isotope data is taken from an unpublished work (Ramanathan: Geochemistry of the thermal springs located along the West Coast, unpublished work) and plotted in the $\delta^{18} \mathrm{O}$ vs. $\delta^{2} \mathrm{H}$ diagram (Figure 6). The $\delta^{18} \mathrm{O}$ and $\delta^{2} \mathrm{H}$ for thermal water is $-1.6 \%$ and $-5 \%$ and for Rajapur river water is $-2.2 \%$ and $-6 \%$, respectively. The thermal spring does not show significant 'oxygen shift' indicating that the spring is not of high-temperature type, which does not attain more than $220^{\circ} \mathrm{C}$ (Nuti 1991), or the residence time may not be sufficient for the exchange to occur.

\section{Geothermometry}

\section{Silica geothermometry}

In 1973, Fournier gave the silica geothermometry for the estimation of the reservoir temperature as follows (Fournier 1973):

Quartz geothermometer with no steam loss:

$$
T\left({ }^{\circ} \mathrm{C}\right)=\frac{1,309}{5.19-\log S}-273.15
$$

Quartz geothermometer with maximum steam loss:

$$
T\left({ }^{\circ} \mathrm{C}\right)=\frac{1,522}{5.75-\log S}-273.15
$$

where $S$ is the concentration of silica in thermal water. The estimated reservoir temperatures based on quartz is always lower than that of the ion-exchange geothermometry because of the quick re-equilibration of quartz to the surroundings (Fournier 1977). The estimated reservoir temperature of $104^{\circ} \mathrm{C}$ and $105^{\circ} \mathrm{C}$, respectively, is considered as the minimum reservoir temperature.

\section{Cation geothermometry}

Cation geothermometers are used to estimate the reservoir temperatures. We have calculated the reservoir temperature using the following formula (Giggenbach 1988):

$$
T\left(C_{\mathrm{kn}}\right)=\frac{1,390}{1.75-\log \left(\frac{\mathrm{K}}{\mathrm{Na}}\right)}
$$

where ' $k n$ ' represents ' $\mathrm{K}$ and $\mathrm{Na}$ ' and $\mathrm{K}$ and $\mathrm{Na}$ are in milligram per liter.

$$
T\left(C_{\mathrm{km}}\right)=\frac{4,410}{14-\log \left(\frac{\mathrm{K}^{2}}{\mathrm{Mg}}\right)}
$$

where ' $\mathrm{km}$ ' represents ' $\mathrm{K}$ and $\mathrm{Mg}$ ' $\mathrm{K}$ and $\mathrm{Mg}$ are in milligram per liter.

The reservoir temperature calculated using the above equations individually gives two different values $\left(281^{\circ} \mathrm{C}\right.$ and $70^{\circ} \mathrm{C}$ respectively) since the reaction involved $\mathrm{K}-\mathrm{Na}$ equilibrates at high temperatures while $\mathrm{K} / \sqrt{ } \mathrm{Mg}$ equilibrates at low temperatures. Further, the reaction involving $\mathrm{K}$ and $\mathrm{Mg}$ equilibrates is faster, and their 
temperatures estimated from surface geothermal waters give very low reservoir temperatures. Reactions involving $\mathrm{K}$ and $\mathrm{Na}$ do not adjust quickly to the physical environment at shallow depths. So in this case, cation geothermometry overestimates the reservoir temperature.

\section{Cation composition geothermometer}

Nieva and Nieva (1987) developed the cation composition geothermometer; the relationship between cations is as follows:

$$
T(\mathrm{~K})=\frac{14,990}{7 \log \left(\frac{\left[\mathrm{Na}^{+}\right]}{\left[\mathrm{K}^{+}\right]}\right)+2 \log \left(\frac{\left[\mathrm{Ca}^{2+}\right]}{\left[\mathrm{Na}^{+}\right]}\right)+2 \log \left(\frac{\left[\mathrm{Mg}^{2+}\right]}{\left[\mathrm{Na}^{+}\right]^{2}}\right)+29.39}
$$

where $[x]$ is the mole concentration of species $x\left(\mathrm{~mol} \mathrm{~kg}^{-1}\right)$.

He divided this equation into four subgroups, and according to this division our data fall in the first subgroup. In the first subgroup, the equation is modified as follows:

$$
T(\mathrm{~K})=\frac{11,140}{6 \log \left(\frac{\left[\mathrm{Na}^{+}\right]}{\left[\mathrm{K}^{+}\right]}\right)+\log \left(\frac{\left[\mathrm{Mg}^{2+}\right]}{\left[\mathrm{Na}^{+}\right]^{2}}\right)+18.30}
$$

With the cation composition geothermometer (CCG), estimated reservoir temperature is $157^{\circ} \mathrm{C}$.

\section{Gravity anomaly}

A gravity contour map was prepared based on the terrain-corrected Bouguer gravity anomaly map of India (2006). The study area shown in Figure 7 is characterized by large negative anomalies $(-80 \mathrm{mGal})$. In parts of Gugi and Rajapur areas, low gravity anomaly was observed.

A gravity profile along the line connecting Rajapur and Gugi (Figure 7) is shown in Figure 8. Near Rajapur, a large gravity anomaly is found due to the presence of the Koyna Rift having an average thickness of 50 km (Krishna Brahmam and Negi 1973; Dobrin 1976; Telford et al. 1990). Another gravity anomaly may be due to the presence of dyke or some high-density rock below the Deccan Trap. The exposed granitic rock in parts of Gugi area resulted in negative gravity anomaly. Therefore, a low gravity anomaly near the Rajapur area suggests the presence of granitic terrain below DVP.

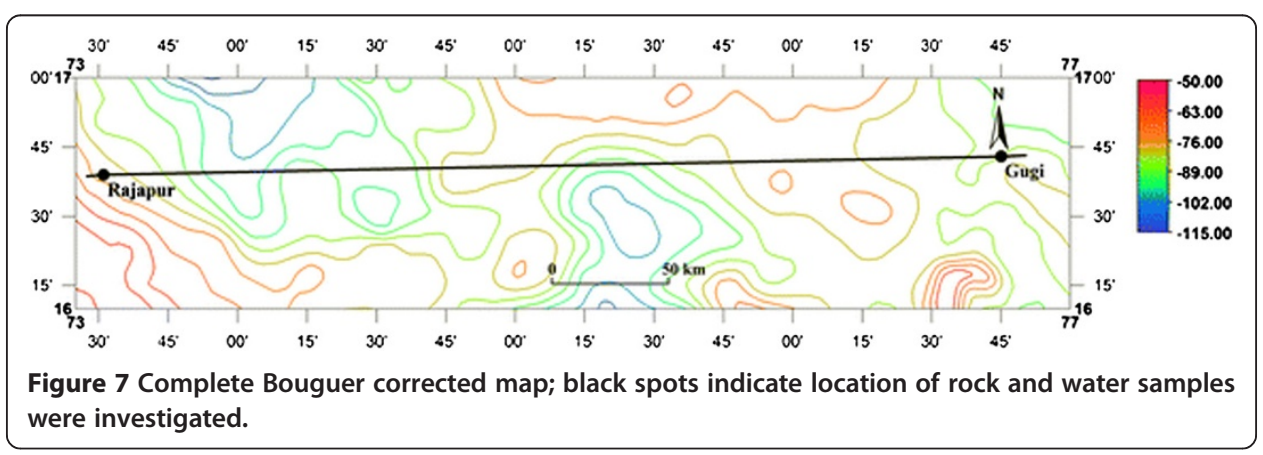




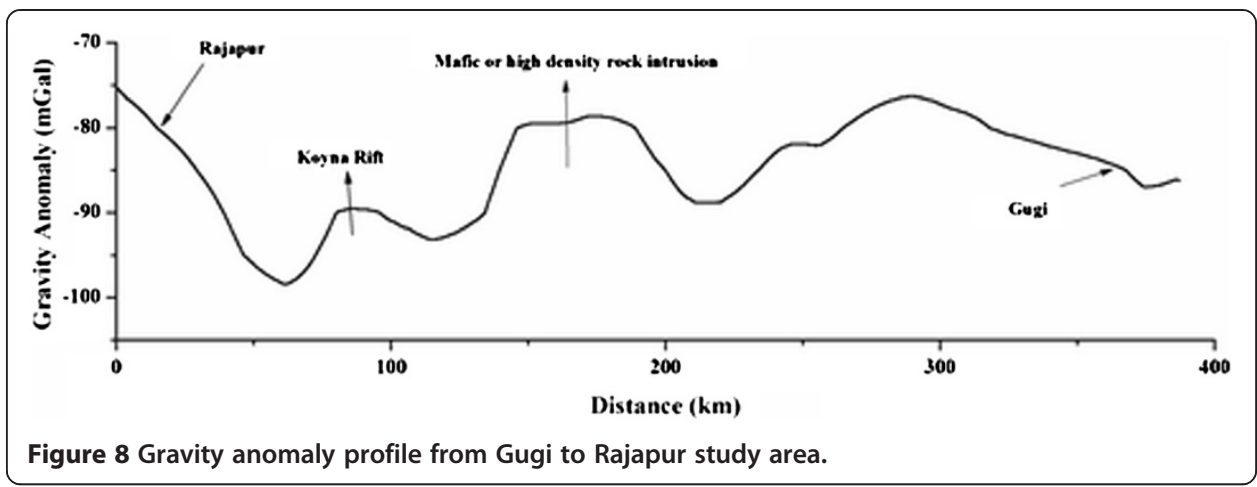

\section{Conclusions}

The Rajapur thermal waters are of $\mathrm{Na}-\mathrm{Ca}-\mathrm{HCO}_{3}$ type, and the stable isotope analysis of thermal and river waters shows a close relationship, which indicates mixing of the geothermal water with the near-surface groundwater. The thermal water is rich in $\mathrm{Na}^{+}, \mathrm{K}^{+}$, $\mathrm{Mg}^{++}$, and $\mathrm{HCO}_{3}^{-}$. Water-rock interaction experimental result shows the circulation of the meteoritic water through granites and emerging as the Rajapur thermal springs. Higher total dissolved solids in thermal water can be ascribed to high-temperature water-rock interaction at great depth. Due to the basalt-water interaction at Rajapur, the $\mathrm{Na}$ to $\mathrm{K}$ and $\mathrm{Mg}$ to $\mathrm{Na}$ ratio and excessive $\mathrm{Ca}$ become less sensitive to temperature variation. The concentration of silica showed a great variation (70 to $400 \mathrm{ppm}$; Chandrasekharam et al. 1992; Ramanathan: Geochemistry of the thermal springs located along the West Coast, unpublished work). Reservoir temperature estimation based on CCG is here considered as reliable, which gave a reservoir temperature of $157^{\circ} \mathrm{C}$. Also, the surface and groundwater from Rajapur show very low concentration of other major ions in comparison to the thermal water in the area (Minissale et al. 2000), whereas the surface and groundwater from Gugi have higher concentrations of major ions with high total dissolved solids. There is no indication of an interaction of seawater with the thermal spring water as is the case of other west coast springs. Thus, the geochemistry of thermal water confirms the location of thermal reservoir to the Precambrian granites underlying the Deccan Basalt.

Radioactive heat production data of granites of Gugi show high values on an average of $42.6 \mathrm{~mW} / \mathrm{m}^{2}$, which are similar to many other potentially viable areas around the world. This is, hence, considered as the greatest possible heat source of the reservoir of the Rajapur thermal springs.

The gravity profile (Figure 7) from Gugi to Rajapur shows a disparity in gravity anomaly, perhaps due to the variation in thickness of the Deccan Flood Basalt. The gravity anomaly in Rajapur is $10 \mathrm{mGal}$, which is lower than others observed in the Gugi area. If we apply complete Bouguer correction in the Rajapur area for the 600-m-thick basalt layer, we find a comparatively similar gravity anomaly as in the Gugi area. Also, the existence of low density rock like granite underlying the DFB cannot be ruled out. With the help of the gravity anomaly, it can be predicted that the main heat source for the Rajapur thermal springs is the granitic batholith, which extends from Gugi to the Rajapur. Finally looking at all these aspects, it can be postulated that the thermal waters from Rajapur area, coming from underneath Dharwar Granitic Batholith and underlying the basaltic terrain, interact with the 

near-surface groundwater on their way to the surface, to emerge as thermal
springs.

\section{Competing interests}

The authors declare that they have no competing interests.

\section{Authors' contributions}

HKS compiled the data, prepared the gravity anomaly map, interpreted the data and drafted the manuscript. YK carried out the experimental work as a part of his M Tech dissertation. TG supervised the experimental work along with participating in drafting the manuscript. Prof DC is our guide/supervisor and guided us throughout the process. BS help to manuscript preparation and data interpretation. All authors read and approved the final manuscript.

\section{Acknowledgments}

Authors are thankful to Prof. S. Vishwanathan for his valuable suggestions to improve the quality of the manuscript.

\section{Author details}

'Department of Earth Sciences, Indian Institute of Technology Bombay, Mumbai, Maharashtra 400076, India.

${ }^{2}$ IITB-Monash Research Academy, Indian Institute of Technology Bombay, Mumbai, Maharashtra 400076, India. ${ }^{3} \mathrm{Civil}$ Engineering Department, Monash University, Clayton, Melbourne, Victoria 3800, Australia.

Received: 23 September 2013 Accepted: 30 January 2014

Published online: 17 May 2014

\section{References}

APHA (1977) Standard methods for examination of water and waste water. American Public Health Association, Water and Waste Product Control Federation. Washington DC, Springer series in statistics, p 1193

Arnorsson S (2000) Isotopic and chemical techniques in geothermal exploration, development and use. Internationa Atomic Energy Agency, Vienna, Austria. 362

Bertin EP (1978) Introduction to X-ray spectrometric analysis. Plenum, New York. 485

Birch F, Roy RF, Decker ER (1968) Heat flow and thermal history in New England and New York. In: Studies of Appalacian geology: northern and maritime. E. Zen, W.S. White, J.B. Hadley and J.B. Thompson Jr, New York: Interscience, pp 437-451

Cermak V, Huckenholz HG, Rybach L, Schmid R (1982) Radioactive heat generation in rocks. In: Hellwege, K. (Ed.), Landolt-Bornstein numerical data and functional relationships in science and technology. New Series, Group V. Geophysics and Space Research, vol. 1, Physical properties of rocks, subvolume b. Springer, Berlin, Heidelberg, New York, pp 433-481

Chandrasekharam D (1985) Structure and evolution of western continental margin of India deduced from gravity, seismic, geomagnetic and geochronological studies. Physics of the Earth and Planetary Interiors 41:186-198

Chandrasekharam D (2000) Geothermal energy resources of India - facts. Proceedings Geothermal Power Asia 2000 Conference, Manila, pp 12-19

Chandrasekharam D (2005) Geothermal energy resource of India: Past and present. Proceedings World Geothermal Congress:1-9

Chandrasekharam D, Chandrasekhar V (2010) Geothermal energy resource, India: country update. In: Proceedings World Geothermal Congress, Bali, Indonesia, 25-29 April 2010. World Geothermal Congress, Bali, pp 1-11

Chandrasekharam D, Ramanathan A, Selvakumar RL (1992) Thermal springs in the Puttur crystallines of the western continental margin of India-field and experimental results in water-rock interaction 7. Kharaka, K. and S. Maest (eds.) , AA Balkema, Netherlands, pp 1272-1274

Dhana RR, Kumar MK, Babu EVSS, Pandit SA (1999) Field workshop on integrated evolution of the Kaladgi and Bhima Basins. Geological Society of India:47-53

Dobrin MB (1976) Introduction to geophysical prospecting, 2nd edition. McGraw-Hill, New York, p 446

Fournier RO (1973) Silica in thermal waters: laboratory and field investigations. Proceedings International Symposium on Hydrogeochemistry and Biogeochemistry, Tokyo 1:122-139

Fournier RO (1977) Chemical geothermometers and mixing models for geothermal systems. Geothermics 5:41-50

Giggenbach WF (1988) Geothermal solute equilibria. Derivation of Na-K-Mg-Ca geoindicators. Geochica et Cosmochimica Acta 52:2749-2765

Glassley EW (2010) Geothermal energy renewable energy and the environment. CRC Press Taylor \& Francis Group, U.S., p 285

Hooper PR (1990) The timing of crustal extension and the eruption of continental flood basalts. Nature 345:246-249

Jaupart C, Marescha JCI (1999) The thermal structure and thickness of continental roots. Lithos 48:93-114

Kale VS, Peshwa W (1995) Bhima basin. Field workshop on Bhima Basin-Field guide. Geological Society of India, Bangalore. 142

Krishna BN, Negi JG (1973) Rift valleys beneath Deccan Traps (India). Geophysical Research Bulletin 11:207-237

Kumar D, Thiagarnajan S, Rai SN (2011) Deciphering geothermal resources in Deccan Trap region using electrical resistivity tomography technique. Journal Geological Society of India 78:541-548

Lachenbruch AH (1968) Preliminary geothermal model of the Sierra Nevada. Journal of Geophysical Research 73:6977-89

Marini L (2010) Geochemical techniques for the exploration and exploration of geothermal energy. Universita degli Studi di Genova, Italia 
Minissale A, Vaselli O, Chandrasekharam D, Magro G, Tassi F, Casiglia A (2000) Origin and evolution of 'intracratonic' thermal fluids from central-western peninsular India. Earth and Planetary Sciences Letters 181:377-394

Muthuraman K (1986) Sea water-basalt interactions and genesis of the coastal thermal waters of Maharashtra, India. Geothermics 15:689-703

Nieva D, Nieva R (1987) Developments in geothermal energy in Mexico-part twelve. A cationic geothermometer for prospecting of geothermal resources. Heat Recovery Systems \& CHP 7:243-258

Nuti S (1991) Isotope techniques in geothermal studies. In: D'amore F (Ed) Applications of geochemistry in geothermal reservoir development, series of technical guides on the use of geothermal energy. UNITAR/UNDP center on small energy resources, Rome, Italy, pp 215-251

Pandit SA, Ali MA, Swarnkar BM, Banerjee DC (1999) Field workshop on integrated evolution of the Kaladgi and Bhima Basins. Geological Society of India:53-56

Paul DK, Kresten P, Barman TR, McNutt RH, Brunfelt AO (1984) Geochemical and petrological relation in some Deccan Basalts, Western Maharashtra, India. Journal of Volcanology and Geothermal Research 21:165-176

Piper M (1944) A graphic procedure in the geochemical interpretation of water-analyses. American Geophysical Union 25:914-923

Ramanathan A, Chandrasekharam D (1997) Geochemistry of Rajapur and Puttur Thermal Springs of the West Coast, India. Journal of Geological Society of India 49:559-565

Rybach L (1976) Radioactive heat production: a physical property determined by the chemistry in the physical and chemistry of minerals and rocks. Strens, R.G.J. (Ed.), Wiley-Interscience, New York, pp 309-318

Senthil Kumar P, Reddy GK (2004) Radioelements and heat production of an exposed Archaean crustal cross-section, Dharwar craton, south India. Earth and Planetary Science Letters 224:309-324

Senthil Kumar P, Srinivasan R (2002) Fertility of Late Archaean basement granite in the vicinity of U-mineralized Neoproterozoic Bhima basin, peninsular India. Current Science 82:571-576

Senthil Kumar P, Menon R, Reddy GK (2007) Crustal geothermal in southern Deccan Basalt Province, India: the Moho is as cold as adjoining cratons. GSA Special Paper 430:275-284

Singh HK, Singh B, Kumar Y, Chandrasekharam D (2012) Evolution of the Rajapur thermal spring, Maharashtra through the Gugi, Karnatka granites with an experimental approach. In: 7th European Congress on Regional Geoscientific Cartography and Sustainable Information Geo-Management Systems. Euregeo, Bologna, pp 467-468

Subbarao KV, Chandrasekharam D, Navneethakrishnan P, Hooper PR (1994) Stratigraphy and structure of parts of the Central Deccan Basalt Province: eruptive models. In: Subbarao KV (ed) Volcanism. Wiley, New Delhi, pp 321-332

Swaminath J, Ramakrishnan M (1981) Early Precambrian supracrustals of southern Karnataka. Mem. Geological Survey of India 112:350

Telford WM, Geldart LP, Sheriff RE (1990) Applied geophysics. 2nd edn. Cambridge University Press, New York. 860 Vaidyanadhan R, Ramakrishnan M (2010) Geology of India. Geological Society of India, Bangalore, India 1:556

doi:10.1186/s40517-014-0002-4

Cite this article as: Singh et al: High-heat-producing granites of East Dharwar Craton around Gugi, Karnataka, and their possible influence on the evolution of Rajapur thermal springs, Deccan Volcanic Province, India.

Geothermal Energy 2014 2:2.

\section{Submit your manuscript to a SpringerOpen ${ }^{\circ}$ journal and benefit from:}

- Convenient online submission

- Rigorous peer review

- Immediate publication on acceptance

- Open access: articles freely available online

- High visibility within the field

Retaining the copyright to your article

Submit your next manuscript at $\boldsymbol{\sim}$ springeropen.com 